\title{
Protease Production by Bacteroides amylophilus Strain H 18
}

\author{
By T. H. BLACKBURN \\ The Rowett Research Institute, Bucksburn, Aberdeen
}

(Accepted for publication 7 March 1968)

\begin{abstract}
SUMMAR Y
Bacteroides amylophilus strain $\mathrm{H} I 8$ produced protease(s), active at $\mathrm{pH} 7 \cdot 0$, when grown anaerobically in a simple maltose, ammonium sulphate, cysteine, sodium bicarbonate and salts medium. Protease production was neither induced nor repressed by a wide range of nutrients. Protease was synthesized by exponentially growing organisms and $20 \%$ of it was liberated into the growth medium. The cell-bound protease was completely accessible to the protein substrate. Protease production was proportional to ammonium sulphate and maltose concentration in the ranges in which these nutrients were growth limiting.
\end{abstract}

\section{INTRODUCTION}

The breakdown of dietary protein in the rumen is a process which has a significant effect on the retention of nitrogen by ruminants (Blackburn, I965). Rumen microorganisms are completely responsible for this proteolysis and bacteria have been shown to be actively implicated (Blackburn \& Hobson, 1960a). Early attempts to isolate the bacteria effecting this protein breakdown resulted in the growth of facultative anaerobes (Appleby, 1955; Blackburn \& Hobson, 1960 b) but the application of more rigorous anaerobic methods resulted in the isolation of true rumen anaerobes which had considerable proteolytic activity (Blackburn \& Hobson, 1962). Most of these bacteria were Gram-negative species, which was considered to be unusual since, with the exception of members of Pseudomonas and Vibrio genera (Pollock, 1962), most bacteria which produce exo-enzymes are Gram-positive. Protease production by Gram-negative anaerobic bacteria has been little investigated; its study thus seemed to be of general interest and it was also hoped that knowledge of the mode of action of these proteases might enable protein hydrolysis in the rumen to be controlled. Bacteroides amylophilus was selected for investigation principally because it rapidly hydrolyses casein in growth media, but it also has other features of interest. Most of the strains examined produced relatively small quantities of free amino acid from protein, indicating the absence of peptidases, and in common with other proteolytic rumen bacteria they appeared to utilize ammonia in preference to preformed amino acids and peptides (Abou Akkada \& Blackburn, 1963). The growth requirements of $B$. amylophilus are very simple and rumen fluid is not essential for its growth, but it has an absolute requirement for maltose or for $\alpha$-I,4-linked glucose polymers (Blackburn \& Hobson, 1962). It produces an active amylase and its capacity to hydrolyse casein is not diminished by subculture. In practical terms the object of this work was to define the conditions for the growth of $B$. amylophilus which would give maximum protease production, so that the proteolytic enzyme(s) might be studied in more detail. To define these conditions the following questions had to be answered: is 
protease production inducible or repressible? At what stage of the growth cycle is proteolytic activity produced, is it liberated free into the growth medium, is it cell bound or is it located intracellularly? If it is liberated free into the growth medium is its appearance associated with cell lysis?

\section{METHODS}

Organism. Bacteroides amylophilus strain $\mathrm{H} 8$ was isolated from a dilution of $1 / 10^{8}$ in a roll tube of casein + rumen fluid medium (Blackburn \& Hobson, 1962), from sheep no. 6 (Blackburn \& Hobson, 1960c). This strain was identical to previous isolates (Blackburn \& Hobson, 1962) and conformed to the description of the type species (Hamlin \& Hungate, I956).

Media. The basal medium, based on that of Hungate (1950), contained (g./1.): $\mathrm{K}_{2} \mathrm{HPO}_{4}, 0.45 ; \mathrm{KH}_{2} \mathrm{PO}_{4}, 0.45 ;\left(\mathrm{NH}_{4}\right)_{2} \mathrm{SO}_{4}, 0.9 ; \mathrm{NaCl}, 0.9 ; \mathrm{MgSO}_{4}, 0.09 ; \mathrm{CaCl}_{2}$, 0.09 ; resazurin, $0.00 \mathrm{I}$; L-cysteine hydrochloride, $0.5 ; \mathrm{NaHCO}_{3}, 5.0$. The mineral and resazurin solutions plus any other additions to the medium were placed in a screwcapped bottle and the volume made to $900 \mathrm{ml}$. with distilled water. The medium was autoclaved at $120^{\circ}$ for $\mathrm{I} 5 \mathrm{~min}$. and the cap screwed tight immediately on removal from the autoclave; this resulted in a partial vacuum in the bottle when it had cooled. Autoclaved $\mathrm{I} \cdot 0 \%(\mathrm{w} / \mathrm{v})$ L-cysteine hydrochloride $(50 \mathrm{ml}$.) and $10 \%(\mathrm{w} / \mathrm{v})$ sodium bicarbonate solution $\left(50 \mathrm{ml}\right.$.) which had been sterilized by heating to $100^{\circ}$ were added to the medium under a stream of oxygen-free $\mathrm{CO}_{2}$. The medium could then be dispensed into tubes closed with rubber-bungs; this and subsequent steps were done under an atmosphere of $\mathrm{CO}_{2}$. Other media constituents were added at $3.0 \mathrm{~g}$./1., except for casein $\left(5^{\circ} \circ \mathrm{g} . / 1\right.$.) and agar $\left(25^{\circ} \circ \mathrm{g} . / 1\right.$.). Yeast extract (Difco) and Tryptose (Bacto) were from Bacto Laboratories, Detroit, U.S.A.; vitamin-free acid hydrolysed casein (Casamino acids) from Allen and Hanbury Ltd., London, E. 2; soluble starch and maltose were AR grade from B.D.H. Ltd., Poole, Dorset; proteose peptone from Oxoid, London, E.C. 4; cysteine hydrochloride from L. Light Ltd., Colnbrook, Bucks.; corn steep liquor (MX9A) from Brown and Polson, Trafford Park, Manchester II. Casein was prepared from Glaxo casein C (Glaxo Ltd., Greenford, Middlesex) by the acid precipitation method of Blackburn \& Hobson (I962). Throughout this paper media are named by their additional constituents, thus maltose medium refers to basal medium $+0.3 \%(\mathrm{w} / \mathrm{v})$ maltose.

Maintenance. A large number of lyophilized suspensions of Bacteroides amylophilus H I 8 was prepared, the suspending fluid being $10 \%(\mathrm{w} / \mathrm{v})$ maltose in sterile horse serum. The bacteria have remained viable for 4 years. The usual drying medium containing $10 \%(\mathrm{w} / \mathrm{v})$ glucose did not yield viable dried bacteria. Stock cultures were maintained on slopes of casein maltose agar medium. Transfers were made each week to fresh slopes by stab inoculation. All cultures were grown at $38^{\circ}$ and inocula generally consisted of 0.01 vol. of log phase bacteria in maltose medium.

Concentration of bacterial cultures. The concentration of bacterial growth was read on an EEL nephelometer (Evans Electroselenium Ltd., Halstree, Essex) set to read IOo against an arbitrary standard of glass fragments suspended in agar. EEL readings were converted into equivalent dry weights of bacteria from a calibration curve, $100 \mathrm{EEL}$ units = equiv. $0.49 \mathrm{mg}$. dry wt bacteria $/ \mathrm{ml}$.

Assay of proteolytic activity. The assay procedure was a modification of the Anson 
(1938) method. Enzyme solution (I ml.) was incubated at $38^{\circ}$ with $4.0 \mathrm{ml}$. of $2.0 \%$ (w/v) casein, $0.0 \mathrm{I} \%$ thiomersalate, in $0 . \mathrm{I} \mathrm{M}-\mathrm{KH}_{2} \mathrm{PO}_{4}$ adjusted to $\mathrm{pH} 7.0$ with $\mathrm{NaOH}$. Immediately after adding the enzyme $2.0 \mathrm{ml}$. of the digest was removed and mixed with $2.0 \mathrm{ml}$. of $0.72 \mathrm{~N}$-trichloroacetic acid. The remaining digest was incubated for up to $24 \mathrm{hr}$ when a further $2.0 \mathrm{ml}$. was precipitated by $2.0 \mathrm{ml}$. of $0.72 \mathrm{~N}$-trichloroacetic acid. At least $30 \mathrm{~min}$. were allowed for the tubes to stand at room temperature and precipitated protein then filtered off on Whatman no. 42 paper. The soluble tyrosine was estimated by adding $\mathrm{I} \cdot 0 \mathrm{ml}$. of filtrate to $5.0 \mathrm{ml}$. of $0.55 \mathrm{M}$-sodium carbonate and making up to $10.0 \mathrm{ml}$. with distilled water. One $\mathrm{ml}$. of $\mathrm{I} / 3 \mathrm{Folin}-$ Ciocalteu reagent (B.D.H. Ltd., Poole, Dorset) was added and mixed in rapidly. The tubes were incubated at $38^{\circ}$ for $30 \mathrm{~min}$. and extinctions were read at $650 \mathrm{~m} \mu$ on an EEL Spectra colorimeter (Evans Electroselenium Ltd., Halstree, Essex). The extinction at zero time was subtracted from the extinction of the test and the value compared with a standard tyrosine curve; I $\mu \mathrm{g}$. tyrosine was equivalent to $E_{650} 0.006 \mathrm{I}$. The plot of extinction against enzyme concentration was linear up to $E_{650} 0.25$ (Fig. I); extinctions higher than this were corrected to the corresponding value on the extrapolation of the linear portion of the curve. The assay of trypsin ( $\times 2$ crystallized, salt free, from L. Light and Co. Ltd., Colnbrook, Bucks.) at $\mathrm{pH} 8 \cdot 0$ under similar conditions gave a similar curve. It was calculated that $\mathrm{I} \cdot 0 \mathrm{ml}$. of the culture (Fig. I) contained proteolytic activity equivalent to $0.9 \mathrm{I} \mu \mathrm{g}$. trypsin. It was because of this relatively low activity that long incubations had to be used. When assaying the proteolytic activity of whole cultures or of supernatant fluids of cultures it was necessary to oxidize the cysteine with iodine, with starch as an indicator (Tracey, I948). This decreased the blank value considerably and gave more reliable results, since cysteine was oxidized to some extent in the enzyme digest but to a lesser extent in the zero time control. A unit of proteolytic activity was defined as the amount of enzyme which would solublize the equivalent of $\mathrm{I} \cdot 0 \mu \mathrm{g}$. tyrosine in I min. Different times of incubation were used, up to $24 \mathrm{hr}$ for preparations of low proteolytic activity, but there was a linear relationship between time of incubation and tyrosine solublized.

\section{RESULTS}

\section{Protease assay}

Proteolytic activity was measured at $\mathrm{pH} 7 \cdot 0$ but there was evidence (Fig. 2 ) that two proteolytic enzymes with optima at $\mathrm{pH} 6.5$ and 8.0 were produced. The relative proportions of these two enzymes varied in different cultures and often there appeared to be a broad optimum from $\mathrm{pH} 6 \cdot 5$ to $8 \cdot 0$.

\section{Ammonia dependence}

The nutritional requirements of Bacteroides amylophilus $\mathrm{H} \mathrm{I} 8$ are very simple and neither growth nor protease production was stimulated by adding to the maltose medium any of the following substances (Bryant \& Robinson, 1962): thiamine $\mathrm{HCl}$, $\mathrm{Ca}$ D-pantothenate, nicotinamide, haemin, riboflavin, pyridoxal (2 mg./l. each); $p$-aminobenzoic acid (I mg./l.); biotin, folic acid, DL-thioctic acid (50 $\mu \mathrm{g} . / 1$. each); cobalamin $(20 \mu \mathrm{g} . / 1$.$) ; sodium acetate. 3 \mathrm{H}_{2} \mathrm{O}(3.06 \mathrm{~g} . / 1$.); sodium isobutyrate ( $7 \mathrm{mg}$./ 1.); sodium valerate, sodium isovalerate, $\mathrm{DL}-\alpha$-methyl- $n$-butyrate (I9 mg./l. each). The addition of rumen fluid $(20 \%, \mathrm{v} / \mathrm{v})$ or corn steep liquor $(0.0 \mathrm{I}-5.0 \%, \mathrm{v} / \mathrm{v})$ was also 


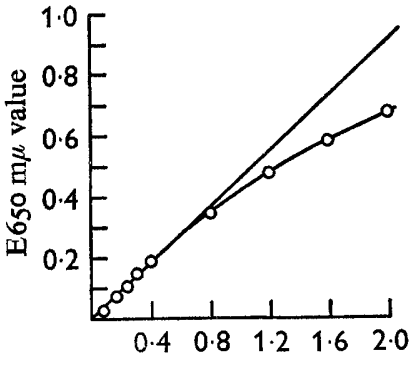

ml. culture

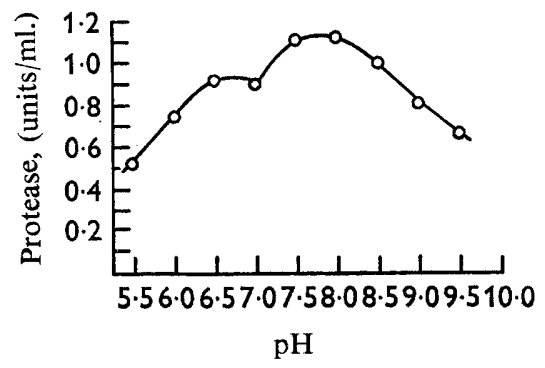

Fig. 2

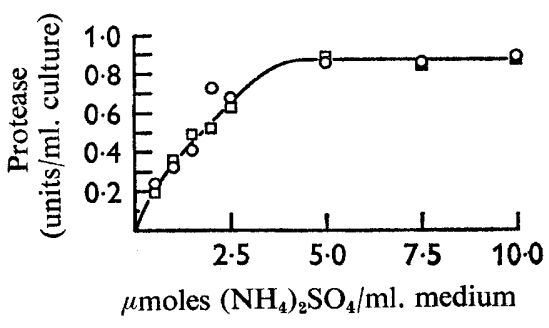

Fig. 3

Fig. 1. Protease concentration curve. The digests contained $80.0 \mathrm{mg}$. casein, $40.0 \mu \mathrm{g}$. thiomersal and 0.4 mmoles $\mathrm{KH}_{2} \mathrm{PO}_{4}$ adjusted to $\mathrm{pH} 7.0$ with $\mathrm{NaOH}$. An I $8 \mathrm{hr}$ culture of Bacteroides amylophilus $\mathrm{H} 8$ in maltose medium was added in amounts up to $2.0 \mathrm{ml}$. and the final volumes were adjusted to $5.0 \mathrm{ml}$. The digests were incubated at $38^{\circ}$ for $20 \mathrm{hr}$ and the trichloroacetic acid-soluble tyrosine was assayed as described in Methods.

Fig. 2. Protease activity of Bacteroides amylophilus $\mathrm{H}$ I 8 protease as affected by $\mathrm{pH}$. One ml. amounts of an $\mathrm{I} 8 \mathrm{hr}$ culture of $B$. amylophilus $\mathrm{HI} 8$ in maltose medium were incubated with $80.0 \mathrm{mg}$. casein, $40.0 \mu \mathrm{g}$ thiomersal and $0.4 \mathrm{mmoles}$ tris adjusted to the correct $\mathrm{pH}$ with maleic acid ( $\mathrm{pH} 5 \cdot 5-7 \cdot 0)$ or $\mathrm{HCl}(\mathrm{pH} 7 \cdot 5-10 \cdot 5)$. The final volume of the digest was $5.0 \mathrm{ml}$. and the proteolytic activity was assayed as described in Methods.

Fig. 3. Ammonium sulphate concentration and protease production by Bacteroides amylophilus H I8. Ammonium sulphate was omitted from the basal medium and was added as a sterile solution to the tubed maltose $(O-O)$ and maltose-tryptose medium $(\square-\square)$ in the concentrations shown. The tubes $(20 \mathrm{ml}$.) were inoculated with a loop from a young culture of $B$. amylophilus $\mathrm{HI} 8$ in maltose medium. The tubes were incubated for $18 \mathrm{hr}$. and the protease activity assayed as described in Methods.

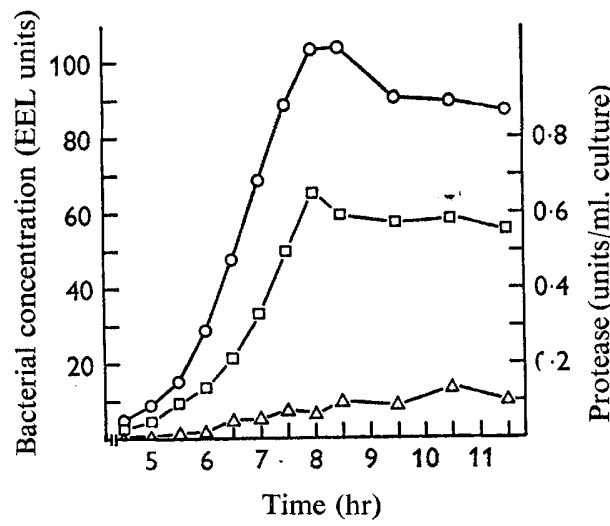

Fig. 4

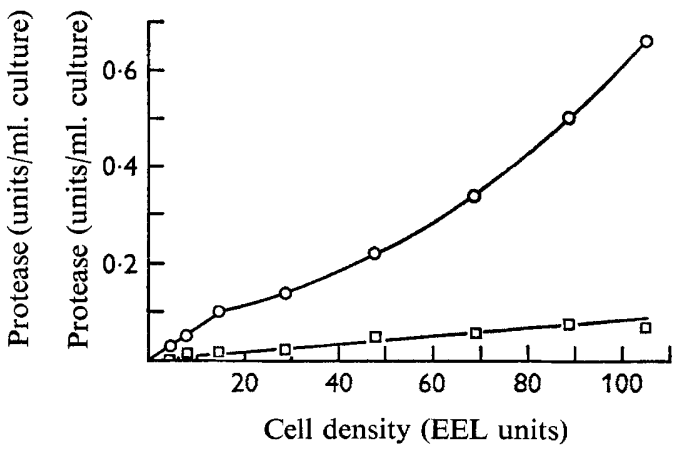

Fig. 5

Fig. 4. Rate of protease production by Bacteroides amylophilus H I $8.250 \mathrm{ml}$. maltose medium was inoculated with $2.0 \mathrm{ml}$. of $18 \mathrm{hr}$ culture of $B$. amylophilus $\mathrm{H}$ I 8 grown in maltose medium. Ten ml. amounts were removed at time intervals and the cell densities were read $(\mathrm{O}-\mathrm{O})$. The proteolytic activity of the whole culture $(\square-\square)$ and of the cell free supernatant (29,000 $g$ Io min.) $(\triangle-\triangle)$ were determined as described in Methods.

Fig. 5. The relationship between cell density and protease production. The data from Fig. 4 are replotted, total protease $(O-O)$ and cell-free protease $(\square-\square)$. 
without effect. Growth and protease production were dependent on the presence of ammonium ions in the growth media. Figure 3 shows that protease production in maltose medium was proportional to ammonium sulphate concentration up to $3.5 \mu$ moles $\left(\mathrm{NH}_{4}\right)_{2} \mathrm{SO}_{4} / \mathrm{ml}$. medium when maltose became limiting; tryptose did not replace ammonium sulphate as a growth factor. The bacterial concentrations showed a similar relationship with ammonium sulphate concentration but were more irregular due to the tendency of $B$. amylophilus to lyse when the bacteria ceased to multiply. The relative rates of production of bacteria and protease are better illustrated in Figs. 4 and 5 . Figure 4 shows plots of bacterial concentration, total and free protease, against age of culture in maltose medium. Protease production began early in the logarithmic phase of growth and continued until the bacteria ceased to divide. The cell-free protease constituted at a maximum $20 \%$ of the total protease and no immediate increase in free protease was associated with the decrease in bacterial concentration. The data in Fig. 4 are replotted in Fig. 5 to show more clearly the relationship of bacterial concentration and protease production. The cell-free protease was proportional to the bacterial concentration but the total protease was not, especially during the midlogarithmic growth phase. The proportion of cell-free $(29,000 \mathrm{~g}$; I0 min.) protease increased in cultures on further incubation to 42,50 and $87 \%$ after 24,48 and $72 \mathrm{hr}$, respectively. The total protease, after $72 \mathrm{hr}$, had fallen to $0.3 \mathrm{I}$ protease units $/ \mathrm{ml}$. which showed a loss of $54 \%$ of the highest activity observed. In the logarithmic phase of growth most of the activity was associated with the intact bacteria. Treatment with toluene or ultrasonic disintegration did not result in an increase of protease, indicating that all the protease was superficially located at the bacterial surface and directly accessible to the casein molecules.

\section{Table I. Effect of organic nitrogen sources on growth and protease production of Bacteroides amylophilus $H \mathrm{I} 8$}

Media compositions and protease assay are described in Methods. The media were incubated for $24 \mathrm{hr}$ and centrifuged $29000 \mathrm{~g}$ for $10 \mathrm{~min}$. Unhydrolysed casein was measured by a Biuret method (Layne, 1957). Cell densities could not be measured in casein-containing media, due to opacity.

\begin{tabular}{|c|c|c|c|c|c|c|c|c|}
\hline & \multicolumn{8}{|c|}{ Medium } \\
\hline & Maltose & $\begin{array}{l}\text { Maltose } \\
\text { tryptose }\end{array}$ & $\begin{array}{l}\text { Maltose } \\
\text { proteose- } \\
\text { peptone }\end{array}$ & $\begin{array}{l}\text { Maltose } \\
\text { Casamino- } \\
\text { acids }\end{array}$ & $\begin{array}{c}\text { Maltose } \\
\text { casein }\end{array}$ & $\begin{array}{l}\text { Maltose } \\
\text { Tryptose } \\
\text { casein }\end{array}$ & $\begin{array}{l}\text { Maltose } \\
\text { Proteose- } \\
\text { peptone } \\
\text { casein }\end{array}$ & $\begin{array}{l}\text { Maltose } \\
\text { Casamino- } \\
\text { acids } \\
\text { casein }\end{array}$ \\
\hline $\begin{array}{l}\text { Total protease } \\
\text { (units } / \mathrm{ml} \text {.) }\end{array}$ & 0.62 & 0.72 & 0.63 & 0.27 & 0.63 & 0.67 & 0.68 & 0.36 \\
\hline $\begin{array}{l}\text { Total protease in } \\
\text { cell-free supernatant } \\
(\%)\end{array}$ & 44 & 39 & 50 & $2 \mathrm{I}$ & 25 & 28 & 29 & 20 \\
\hline $\begin{array}{l}\text { Casein hydrolysed } \\
(\%)\end{array}$ & - & - & - & - & 80 & 83 & 83 & 87 \\
\hline $\begin{array}{l}\text { Cell density (EEL } \\
\text { units) }\end{array}$ & 77 & 60 & 96 & 49 & - & - & - & - \\
\hline
\end{tabular}

\section{Effect of organic nitrogen}

It was observed (Fig. 3) that the presence of tryptose did not stimulate protease production, nor did mixtures of tryptose, proteose peptone and Casamino acids with casein (Table I). The bacterial concentrations in $24 \mathrm{hr}$ cultures have little significance 
but there was definite inhibition of growth by $0.3 \%(\mathrm{w} / \mathrm{v})$ Casamino acids. In experiments not reported this inhibition by $0.3 \%(\mathrm{w} / \mathrm{v})$ or more Casamino acids was confirmed, while lower concentrations were without effect in influencing growth and protease production. A considerable proportion of the casein originally present $(50 \mathrm{mg}$.) $\mathrm{ml}$. growth medium) was hydrolysed in all the media, irrespective of their composition. That tryptose and proteose peptone were without effect on growth rate and protease production is illustrated in Fig. 6 . The mean generation time in all media was $68 \mathrm{~min}$. The addition ( $5 \mathrm{~g}$./1.) of glutamic acid, aspartic acid, lysine or arginine did not allow Bacteroides amylophilus $\mathrm{H} \mathbf{\mathrm { I }} 8$ to grow in the basal medium and had no effect on growth or protease production in the maltose medium.
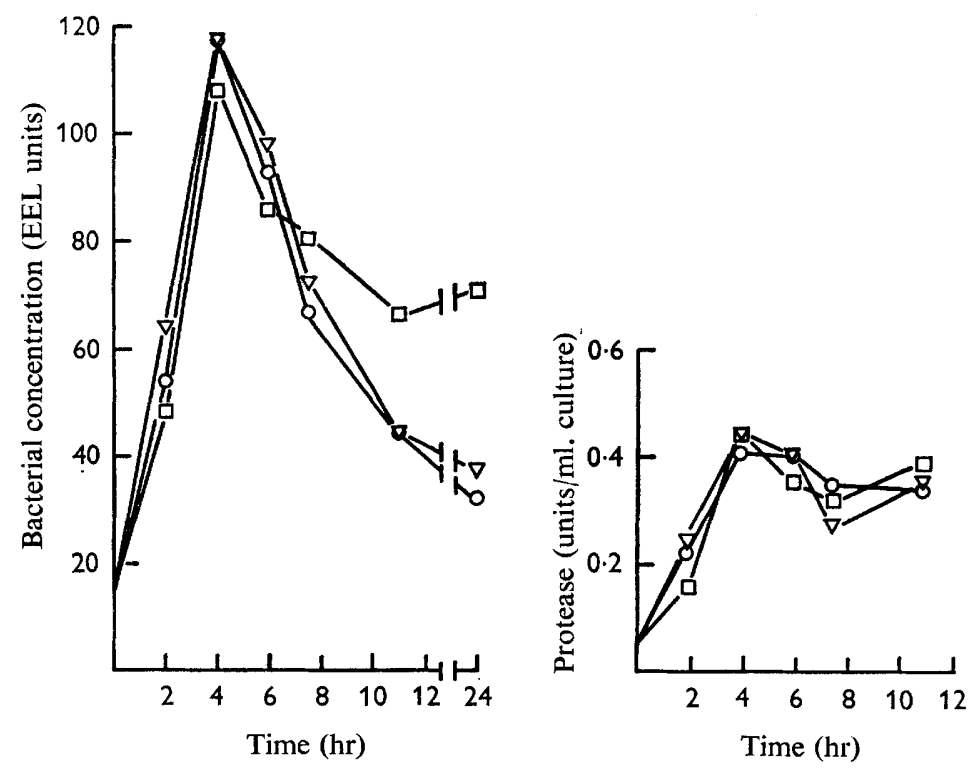

Fig. 6. Protease production by Bacteroides amylophilus $\mathrm{HI} 8$. Three $20 \mathrm{ml}$. $\mathrm{I} 6 \mathrm{hr}$ cultures of B. amylophilus $\mathrm{HI} 8$ in maltose medium were sedimented at $3000 \mathrm{~g}$ for $10 \mathrm{~min}$. and the cells inoculated directly into $100 \mathrm{ml}$. bottles of: maltose medium ( $\square-\square$ ), maltose-tryptose medium $(O-O)$ maltose-proteose and peptone medium $(\nabla-\nabla)$. The bottles were incubated and samples removed for cell density and protease determinations as described in Methods.

\section{Table 2. The fermentation products of Bacteroides amylophilus $\mathrm{H}$ I8}

The four media were inoculated and incubated for $24 \mathrm{hr}$. The fermentation products were separated and assayed by the method of Wiseman \& Irwin (I957).

\begin{tabular}{|c|c|c|c|c|}
\hline \multirow[b]{2}{*}{ Products } & \multicolumn{4}{|c|}{ Medium } \\
\hline & Maltose & $\begin{array}{l}\text { Maltose } \\
\text { Tryptose }\end{array}$ & $\begin{array}{c}\text { Maltose } \\
\text { casein }\end{array}$ & $\begin{array}{c}\text { Maltose } \\
\text { Tryptose } \\
\text { casein }\end{array}$ \\
\hline 10 & $11 \cdot 7$ & 15.9 & II $\cdot 7$ & I2.7 \\
\hline moles & II 5 & II 4 & $8 \cdot I$ & $14 \cdot 4$ \\
\hline $\mathrm{c}$ acid $(\mu \mathrm{moles} / \mathrm{ml})$. & $\mathrm{I} 4 \cdot 2$ & 13.5 & $I 2 \cdot I$ & I 2.8 \\
\hline
\end{tabular}




\section{Maltose utilization}

The final products of protein degradation in the rumen include branched- and straight-chain volatile fatty acids (Blackburn, 1965) but the data in Table 2 do not suggest that tryptose or casein were degraded in this way by Bacteroides amylophilus $\mathrm{HI}$, as no increment was found in acetic or formic acid concentrations in media con-

\section{Table 3. Effect of maltose concentration on growth yields and protease of Bacteroides amylophilus $\mathrm{H} I 8$}

\begin{tabular}{|c|c|c|c|c|c|c|}
\hline $\begin{array}{l}\text { Initial } \\
\text { maltose } \\
\text { concen- } \\
\text { tration } \\
(\mathrm{mg} . / \mathrm{ml} .)\end{array}$ & $\begin{array}{l}\text { Final } \\
\text { maltose } \\
\text { concen- } \\
\text { tration } \\
\text { (mg./ml.) }\end{array}$ & $\begin{array}{l}\text { Maltose } \\
\text { used } \\
\text { (mg./ml.) }\end{array}$ & $\begin{array}{c}\text { Cell } \\
\text { density } \\
\text { (EEL/ } \\
\text { units) }\end{array}$ & $\begin{array}{c}\text { Protease } \\
\text { (units/ml.) }\end{array}$ & $\begin{array}{l}\text { Cell yield } \\
\text { (g. cells/ } \\
\text { mole } \\
\text { maltose) }\end{array}$ & $\begin{array}{c}\text { Protease } \\
\text { yield } \\
\text { (units } / \mathrm{mg} . \\
\text { maltose) }\end{array}$ \\
\hline $1 \cdot 16$ & 0.32 & 0.84 & 20 & O.OI & $39 \cdot 8$ & 0.01 \\
\hline $2 \cdot 30$ & 0.46 & $1 \cdot 84$ & $4 I$ & 0.39 & $37 \cdot 4$ & 0.21 \\
\hline $3 \cdot 21$ & 0.48 & $2 \cdot 73$ & $5 \mathrm{I}$ & 0.65 & $31 \cdot 4$ & 0.24 \\
\hline 4.88 & $1 \cdot 38$ & 3.50 & 100 & 0.74 & $47^{\cdot 6}$ & 0.21 \\
\hline 6.50 & 1.90 & $4 \cdot 60$ & 102 & 0.92 & $37 \cdot 2$ & 0.20 \\
\hline $7 \cdot 62$ & 3.60 & 4.02 & 98 & 0.78 & $40 \cdot 8$ & 0.19 \\
\hline $8 \cdot 89$ & $4 \cdot 83$ & 4.06 & 100 & 0.82 & $40 \cdot 6$ & 0.20 \\
\hline $9 \cdot 45$ & 5.85 & 3.60 & 101 & 0.78 & $47^{\circ} 0$ & 0.22 \\
\hline
\end{tabular}

taining tryptose or casein, and no other volatile fatty acids were produced. Carbon dioxide was an essential growth factor for $B$. amylophilus $\mathrm{H} 18$ and the fermentation products suggest that: maltose $+2 \mathrm{CO}_{2} \rightarrow 2$ acetic acid +2 formic acid +2 succinic acid. Yields of bacteria and protease were proportional to the amount of maltose fermented and the total yield of both, expressed per ml. culture, increased up to a maltose concentration of $0.6 \%(\mathrm{w} / \mathrm{v})$ (Table 3). The average yield of bacteria was equivalent to $40 \mathrm{~g}$. dry wt/mole maltose. A high concentration of maltose remained unfermented even where it was growth-limiting.

\section{Utilization of other energy sources}

Growth and protease production occurred to the same extent in starch medium as in maltose medium and the addition of casein, tryptose or Casamino acids did not stimulate further protease production. Casein was hydrolysed in starch media and autolysis of the bacteria also occurred. No energy source other than $\alpha$-I,4-linked glucose polymers was found to support growth, and the presence of $\alpha$-oxoglutaric acid, pyruvic acid, succinic acid, acetic acid, butyric acid or formic acid ( $5 \mathrm{~g}$./1.) did not affect growth or protease production.

Bacteroides amylophilus $\mathrm{HI} 8$ produced small colonies in roll tubes of casein agar medium containing maltose at $0.2 \mathrm{~g}$. $/ \mathrm{l}$. These colonies were surrounded by a dense zone of opacity and when transferred to casein maltose slopes they produced a similar dense opacity in the casein. A total of five transfers on slopes of this medium did not produce an inoculum capable of growth in a liquid medium of the same composition. 


\section{Effect of $p H$ value of medium}

The $\mathrm{pH}$ value of the basal medium, which contained $0.5 \%$ (w/v) $\mathrm{NaHCO}_{3}$, was pH 6.7 when equilibrated with a $100 \% \mathrm{CO}_{2}$ gas-phase. The buffering capacity of this medium was very poor and Bacteroides amylophilus $\mathrm{H}$ I 8 when supplied with a surplus of maltose, lowered the medium to $\mathrm{pH} 5.5$ after $26 \mathrm{hr}$. As shown in Table 4 the presence of twice the usual $\mathrm{NaHCO}_{3}$ concentration resulted in an increase to only $\mathrm{pH} 6 \cdot 9$, but after $26 \mathrm{hr}$ the $\mathrm{pH}$ value had decreased less than in the normal medium. The protease yields in this experiment were very low and the yield at $26 \mathrm{hr}$ was not greatly increased by the additional buffering of the medium, but on further incubation the yield almost doubled in the well buffered medium while it fell in the normal medium.

\section{Table 4. Effect of additional buffering on protease production}

$2.0 \%$ maltose was used instead of the usual $0.3 \%$ to ensure that maltose was not growth limiting. Twice the normal concentration of $\mathrm{NaHCO}_{3}$ was added to one medium. $100 \mathrm{ml}$. amounts of the media were inoculated and samples withdrawn at 26 and $52 \mathrm{hr}$ for $\mathrm{pH}$, cell density and protease determinations, as described in Methods.

\begin{tabular}{|c|c|c|c|c|c|c|}
\hline \multirow[b]{2}{*}{$\mathrm{Hr}$} & \multicolumn{3}{|c|}{ Basal medium $+2.0 \%(w / v)$ maltose } & \multicolumn{3}{|c|}{$\begin{array}{l}\text { Basal medium }+2.0 \%(\mathrm{w} / \mathrm{v}) \text { maltose }+ \\
\text { additional } 0.5 \%(\mathrm{w} / \mathrm{v}) \mathrm{NaHCO}_{3}\end{array}$} \\
\hline & $\mathrm{pH}$ & $\begin{array}{l}\text { Cell density } \\
\text { (EEL units) }\end{array}$ & $\begin{array}{l}\text { Protease } \\
\text { (units } / \mathrm{ml} \text {.) }\end{array}$ & $\mathrm{pH}$ & $\begin{array}{l}\text { Cell density } \\
\text { (EEL units) }\end{array}$ & $\begin{array}{l}\text { Protease } \\
\text { (units } / \mathrm{ml} \text { ) }\end{array}$ \\
\hline 0 & $6 \cdot 7$ & 0 & 0 & 6.9 & 0 & 0 \\
\hline 26 & 5.5 & 94 & 0.20 & $6 \cdot 4$ & 93 & 0.25 \\
\hline 52 & 5.5 & 88 & 0.18 & $5 \cdot 3$ & 122 & 0.47 \\
\hline
\end{tabular}

Effect of $E_{h}$ value of media

The addition of $\mathrm{Na}_{2} \mathrm{~S} .9 \mathrm{H}_{2} \mathrm{O}(0.025 \%)$ to the maltose medium (containing cysteine) did not affect growth or protease production. A similar result was obtained when sodium dithionite $(0.003 \%)$ was used. The concentration of sodium dithionite used reduced phenosafranine; the measured reduction potential of this medium was $-4 \mathrm{IO}$ to $-470 \mathrm{mV}$ (Pt and calomel electrodes).

Bacteroides amylophilus $\mathrm{H}$ I 8 grew in media in which cysteine was replaced by sodium dithionite or by sodium sulphide + ascorbic acid (0.05\%). L-Methionine (0.05\%) could not replace cysteine in media reduced by ascorbic acid. Protease production was similar in all media in which growth occurred.

\section{Effect of cations in media}

A fivefold increase in the normal concentration of $\mathrm{Ca}^{2+}$ or of $\mathrm{Mg}^{2+}$ did not increase either growth or protease production by Bacteroides amylophilus HI8. Further supplementation of the maltose medium with similar concentrations $(0.45 \mathrm{~g} . / 1$. $)$ of $\mathrm{MnCl}_{2}, \mathrm{CoCl}_{2}$ or $\mathrm{FeSO}_{4}$ was without effect.

\section{DISCUSSION}

The curve for activity against $\mathrm{pH}$ of the Bacteroides amylophilus protease suggested the presence of two enzymes, although Matsubara et al. (1958) showed that the crystalline protease of Bacillus subtilis strain $\mathrm{N}$ has an irregular plateau of activity 
from $\mathrm{pH} 7 \cdot 0$ to $\mathrm{pH}$ i $1 \cdot 0$. Production of total protease began with bacterial division and ceased when growth stopped and a small, but constant, proportion (20\%) of the protease was released into the medium. This may be truly extracellular (Pollock, 1962) as was the extracellular $\mathrm{pH} 5.7$ micrococcus protease of McDonald (1965). However, on prolonged incubation the total protease content of a culture decreased but the proportion of cell-free protease increased and this and the very sharp decrease in culture density at the end of logarithmic growth, a characteristic of many rumen bacteria (Bryant \& Robinson, I96I), might indicate that a proportion of bacteria were lysing during growth and that this became apparent only when growth ceased.

The protease production was not subject to either product repression or induction since protein, peptides or amino acids in the medium did not influence its formation, nor was a general metabolic repression demonstrated. The growth requirements of Bacteroides amylophilus are simple and additional nutrients did not affect either growth or protease production. The observations of Hobson, McDougall \& Summers (1968) that some $93 \%$ of the cell nitrogen could be accounted for by ammonia- ${ }^{15} \mathrm{~N}$ disappearance in media with and without additional identified sources of nitrogen confirmed the results of Abou Akkada \& Blackburn (1963) and explain the fact that additional organic nitrogen sources did not influence growth, except that the presence of $0.1 \%(\mathrm{w} / \mathrm{v})$ tryptose in the medium did decrease the lag period, probably by stabilizing the $E_{h}$ value.

The products of maltose fermentation, acetic, formic and succinic acids were those found by Hamlin \& Hungate (1956). The absolute dependence of Bacteroides amylophilus $\mathrm{H}$ I 8 on maltose or starch as energy source made it impossible to investigate the effect of different energy sources on protease production. Presumably the cell is impermeable to a wide range of energy sources but is permeable to $\alpha$-I,4-linked polymers of glucose as is the Micrococcus sp. ATCC 407 (Williams \& McDonald, 1966). Bacteroides amylophilus $\mathrm{H} 8$ lacks the capacity to utilize maltose at concentrations less than $0.32 \mathrm{mg}$. maltose/ml. Hobson \& Summers (1967) also noted this property of B. amylophilus $\mathrm{H}$ I8, and to a lesser extent Ruminococcus albus (Hungate, 1963) showed an impaired ability to concentrate, in this case, cellobiose.

I thank Dr P. N. Hobson for helpful discussion and Mrs N. Cowie for skilled technical assistance.

\section{REFERENCES}

Abou Akkada, A. R. \& Blackburn, T. H. (1963). Some observations on the nitrogen metabolism of rumen proteolytic bacteria. J. gen. Microbiol. 3r, 46I.

Anson, M. L. (1938). The estimation of pepsin, trypsin, papain and cathepsin with haemoglobin. J. gen. Physiol. 22, 79.

APPLEBY, J. C. (1955). The isolation and classification of proteolytic bacteria from the rumen of sheep J. gen. Microbiol. 12, 526.

Blackburn, T. H. (1965). Nitrogen metabolism in the rumen. In Physiology of Digestion in the Ruminant. Ed. by R. W. Dougherty. p. 322. Washington and London: Butterworths.

Blackburn, T. H. \& Hobson, P. N. (1960a). Proteolysis in the sheep rumen by whole and fractionated rumen contents. J. gen. Microbiol. 22, 272.

BlackbuRn, T. H. \& Hobson, P. N. $(1960 b)$. Isolation of proteolytic bacteria from the sheep rumen. J. gen. Microbiol. 22, 282.

Blackburn, T. H. \& Hobson, P. N. $(1960 c)$. The degradation of protein in the rumen of sheep and redistribution of protein nitrogen after feeding. Br. J. Nutr. 14, 445 . 
Blackburn, T. H. \& Hobson, P. N. (I962). Further studies on the isolation of proteolytic bacteria from the sheep rumen. J. gen. Microbiol. 29, 69.

BRyant, M. P. \& Robinson, I. M. (196r). Some nutritional requirements of the genus Ruminococcus. Appl. Microbiol. 9, 9r.

BRYANT, M. P. \& RoBINSON, I. M. (1962). Some nutritional characteristics of predominant culturable ruminal bacteria. J. Bact. 84, 605.

Fairbairn, N. J. (1953). A modified anthrone reagent. Chemy Ind. p. 86.

Hamlin, L. J. \& Hungate, R. E. (1956). Culture and physiology of a starch-digesting bacterium (Bacteroides amylophilus n.sp.) from the bovine rumen. J. Bact. 72, 548 .

Hobson, P. N. \& Summers, R. (I967). The continuous culture of anaerobic bacteria. J. gen. Microbiol. $47,53$.

Hobson, P. N., McDougall, I. E. \& Summers, R. (I968). The nitrogen sources of Bacteroides amylophilus. J. gen. Microbiol. 50, I.

Hungate, R. E. (1950). The anaerobic mesophilic cellulolytic bacteria. Bact. Rev. 14, I.

Hungate, R. E. (I963). Polysaccharide storage and growth efficiency in Ruminococcus albus, J. Bact. 86,848 .

LAYNE, E. (1957). Spectrophotometric and turbidimetric methods for measuring proteins. Meth. Enzymol. 3, 447.

MCDonald, I. J. (1965). Distribution of proteinase in cultures of a species of Micrococcus in synthetic medium. Can. J. Microbiol. II, 693.

Matsubara, H., Hagihara, B., Nakai, M., Konaki, T., Yonetani, T. \& Okunuki, K. (1958). Crystalline bacterial proteinase. II. General properties of crystalline proteinase of Bacillus subtilis N. J. Biochem., Tokyo 45, $25 \mathrm{I}$.

Pollock, M. R. (1962). Exoenzymes. In The Bacteria. Ed. I. C. Gunsalus and R. Y. Stanier, Vol. 4. p. I2 I. New York and London: Academic Press. Inc.

TraceY, M. V. (1948). Leaf protease of tobacco and other plants. Biochem. J. 42, $28 \mathrm{I}$.

Williams, P. J. LE B. \& McDonald, I. J. (I966). Permeability of a micrococcal cell to maltose and some related sugars. Can. J. Microbiol. 12, I2 13.

Wiseman, H. G. \& IRWIN, H. M. (I957). Determination of organic acids in silage. J. agric. Fd. Chem. $5,213$. 